\title{
Sociobiology
}

SHORT NOTE

\section{Discovery of the termite specialist ant genus Centromyrmex, Mayr 1866 (Hymenoptera: Formicidae: Ponerinae) for the Guiana Shield}

\author{
W FRANCO, RM FEITOSA \\ 1 - Departamento de Zoologia, Universidade Federal do Paraná (UFPR), Curitiba-PR, Brazil
}

\author{
Article History

\section{Edited by} \\ Gilberto M. M. Santos, UEFS, Brazil \\ Received $\quad 06$ September 2017 \\ Initial acceptance 02 November 2017 \\ Final acceptance 12 November 2017 \\ Publication date 09 July 2018

\section{Keywords} \\ New records, Distribution, Guiana Shield, \\ Amazon Forest, Poneroid. \\ Corresponding author \\ Weslly Franco \\ Laboratório de Sistemática e Biologia de \\ Formigas - LSBF \\ Departamento de Zoologia \\ Universidade Federal do Paraná- UFPR \\ Av. Cel. Francisco H. dos Santos, 210 \\ CEP 81531-970 - Curitiba-PR, Brasil. \\ E-Mail: weslly.franco@gmail.com
}

\begin{abstract}
The ponerine ant genus Centromyrmex is recorded for the first time in French Guiana. The specimens reported here were collected by the SEAG (Société Entomologique Antilles-Guyane) team in the commune of Saül, French Guiana. The ants were collected in a region of Amazon Forest with flight interception traps. Two out of the three species currently recognized for the genus in South America were here recorded in French Guiana, Centromyrmex alfaroi and Centromyrmex gigas. In total, 24 specimens were collected, all represented by alate queens. This record expands the knowledge about the distribution of this rarely collected genus and reinforces the importance of alternative sampling techniques for collecting cryptobiotic ants and unknown alate forms.
\end{abstract}

The ant genus Centromyrmex Mayr, 1866 (Formicidae: Ponerinae) is a relatively small genus with 15 species worldwide. Morphologically, the genus is easily recognized by the lack of eyes, smooth cuticle, presence of spiniform setae on the mesotibiae and laterally-opening metapleural gland orifices, situated just below the propodeal spiracle. Of these characters, only the last is truly autapomorphic for Centromyrmex (Schmidt \& Shattuck, 2014).

Very little is known about the behavior of Centromyrmex, and the few observations on the species biology suggest that all species in this genus are obligatory predators of termites (Schmidt \& Shattuck, 2014).

The habits are clearly subterranean and the species of Centromyrmex are well adapted to a hypogeic and fossorial lifestyle. This is evidenced by the presence of morphological features commonly found in other hypogeic ants such as their relatively smooth cuticles, lack of eyes in the workers, and the short, powerful, spiny legs that facilitate their movement through the substrates they inhabit (Kempf, 1967; Dejean \& Fénéron, 1999; Bolton \& Fisher, 2008).

Nesting sites are usually near or inside termitaries. Despite rarely collected, workers are usually found inside their prey's nests, upper soil layers, beneath leaf litter, or in rotten logs (Delabie, 1995; Bolton \& Fisher, 2008).

Centromyrmex is a cosmopolitan genus with a mostly tropical distribution. Most of species in the genus are found in the Afrotropics, where 11 species are registered. Three species are currently known from the Neotropics: Centromyrmex alfaroi Emery, 1890; Centromyrmex brachycola (Roger, 1861) and Centromyrmex gigas Forel, 1911. According to Kempf (1967), these three Neotropical species represent the brachycola group of the genus.

In the Neotropics, Centromyrmex is relatively widely distributed. The species of the brachycola group are known for Argentina, Brazil, Bolivia, Colombia, Costa Rica, Ecuador, Panama, Paraguay, Trinidad and Tobago, and Venezuela. 
The northernmost occurrence locality for the genus is Costa Rica and the southernmost limit is the province of Misiones, Argentina. Despite this, the distribution of Centromyrmex present several localities, principally in the South America, where there is no record for the genus.

In this work, we report the first records of two species of Centromyrmex for French Guiana, extending the distribution limits for the genus.

The specimens reported here were identified among the ants collected by the SEAG (Société Entomologique AntillesGuyane) team during the year 2011 in the commune of Saül, French Guiana ( $3^{\circ} 37^{\prime} 22^{\prime \prime} \mathrm{N}$ and $53^{\circ} 12^{\prime} 57^{\prime \prime} \mathrm{W}$ ), an overseas department of France in South America. The locality where the genus was recorded belongs to the Parc amazonien de Guyane, a national park created to protect part of the Amazon Forest in the country.

Ant specimens were collected with SLAM traps (MegaView Science, Taichung City, Taiwan) a variant of the malaise trap (Sand, Land and Air Malaises). Malaise traps are among the most widely used trapping devices for insect collection (Matthews \& Matthews, 1971). The operation of the trap is based on the interception of the flight trajectory of the insects by a fine mesh fabric which acts as a vertical barrier. The SLAM trap is a self-supporting trap mounted on a flexible "igloo tent" structure (Dodds et al., 2015; McCravy, 2017).

The ants collected by the SEAG team were donated to the Laboratório de Sistemática e Biologia de Formigas da Universidade Federal do Paraná, Curitiba, Paraná, Brazil, where the samples were processed. The species of Centromyrmex were identified using the key available in Kempf (1967). Vouchers were deposited in the Padre Jesus Santiago Moure Entomological Collection at the Universidade Federal do Paraná (DZUP).

High resolution images were obtained under a Leica M125 stereomicroscope attached to a Leica DFC 295 video camera at the DZUP. The images of the layers were aligned and combined in program Zerene Stacker v. 1.04, and posteriorly treated in Adobe Photoshop CS6 for brightness and contrast corrections.

The distribution map was generated by the software QGIS 2.18.11 with coordinates imported from Google Earth after consulting the records for Centromyrmex in the literature.

Two species of Centromyrmex were identified among the ants collected by SEAG, namely Centromyrmex gigas and Centromyrmex alfaroi, with 19 and five individuals recovered from the samples, respectively. All the 24 specimens captured are alate queens, which could be securely identified to species since they match most of the diagnostic characters of the species (Fig 1). This represents the first record of the genus from French Guiana.

Both species recorded here appear to be termitophagous, as commonly reported for the genus (Baccaro et al., 2015). Specimens of Centromyrmex gigas are relatively large, with distinctly dentate mandibles, head distinctly broader than

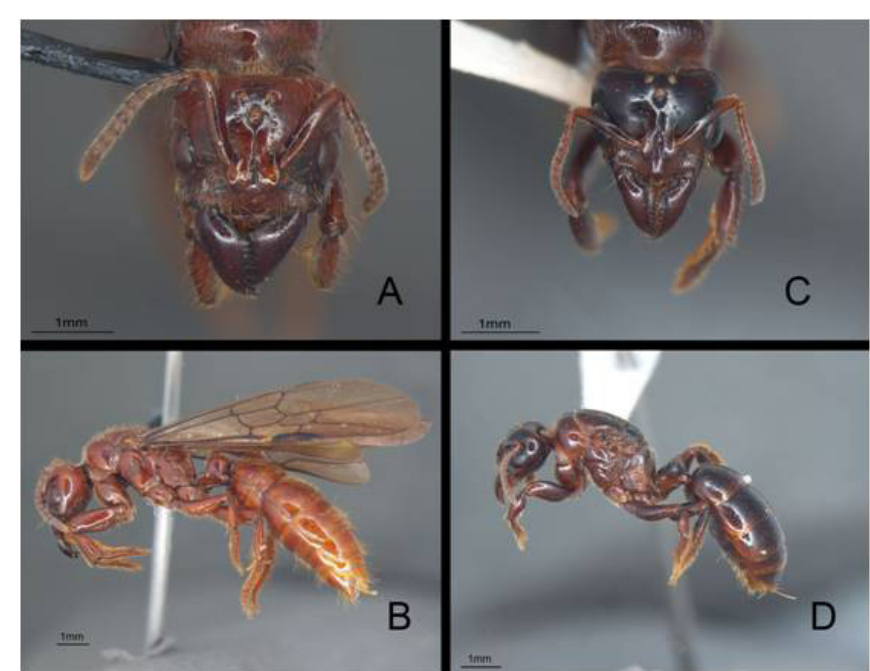

Fig 1. Centromyrmex species of French Guiana. Centromyrmex gigas (A, B); Centromyrmex alfaroi (C, D). A, C: full-face view; B, D: body in lateral view.

long, clypeus without a median tumulus, and the petiole with a long subpetiolar process. The integument is reddish brown to amber-colored (Kempf, 1967). This species is frequently found in nests of Syntermes spp. termites (Delabie, 1995).

Centromyrmex alfaroi is smaller than Centromyrmex gigas, with a broader head, clypeus with an elevated median tumulus subpetiolar process rather short. The color is dark ferruginous. The biology is unknown, but the few specimens observed alive are presumed entirely subterranean (Kempf, 1967).

Until now, Centromyrmex gigas was known only from Argentina and Brazil. The species was recorded in the lower Amazon Valley (states of Pará, Amapá, Roraima, and Amazonas), and in the central and southeastern states of Brazil (Goiás, Bahia, São Paulo, and Rio de Janeiro). The only record of $C$. gigas outside Brazil so far corresponds to the province of Missiones, Argentina, representing the southernmost locality for the occurrence of this genus in the Neotropical region (Fig 2).

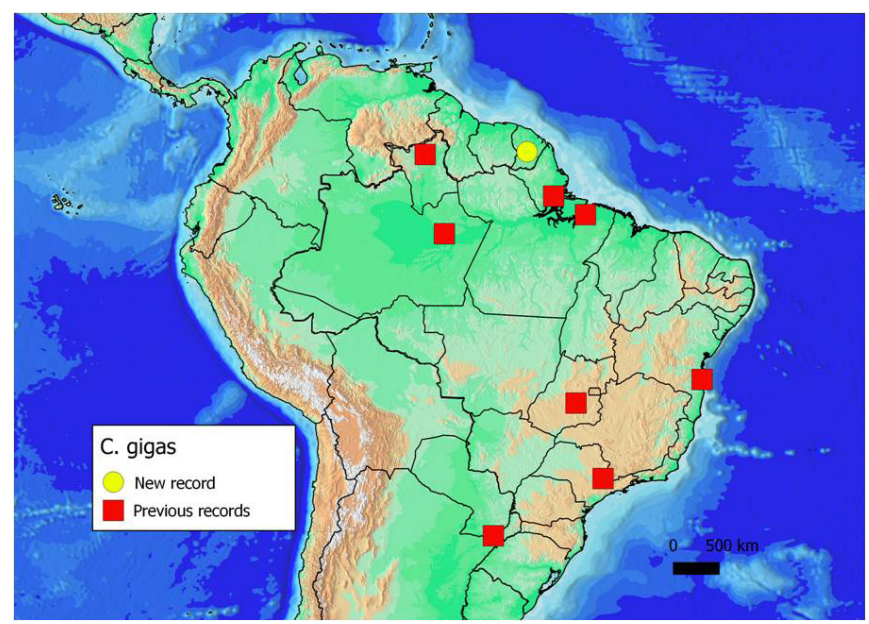

Fig 2. Distribution map of Centromyrmex gigas in the Neotropics based on literature records and the present study. 
Centromyrmex alfaroi is a relatively widely distributed species, with records from Brazil (states of Roraima, Bahia, Goiás, Minas Gerais, and São Paulo); Bolivia; Ecuador; Colombia; Costa Rica and Panamá (Fig 3).

The records presented here extend the distribution of C. gigas and C. alfaroi in the Amazon Region in more than $900 \mathrm{~km}$ to the west from the previously westernmost record in Roraima, Brazil.

The cryptic habits, small colonies and the low local abundance make it rare for ant inventories to detect species of Centromyrmex by the conventional sampling techniques applied for ants. For this reason, the genus distribution presents major gaps in the Neotropical region. The Centromyrmex specimens recorded here are alate (sexual) forms captured by flight interception traps. Information on the sexual forms are of primary interest in ant taxonomy, since most of the specimens deposited in myrmecological collections are wingless (workers). This is especially true for cryptobiotic ants. Also, information about the phenology of ant nuptial flights is largely unavailable, and limited to a few taxa (Feitosa et al., 2016).

Our results reinforce the idea that applying different sampling methods is essential to improve our ability of recording cryptobiotic groups (Bestelmeyer et al., 2000), and that the use of flight interception traps has the potential to greatly improve our knowledge on ant biology and distribution.

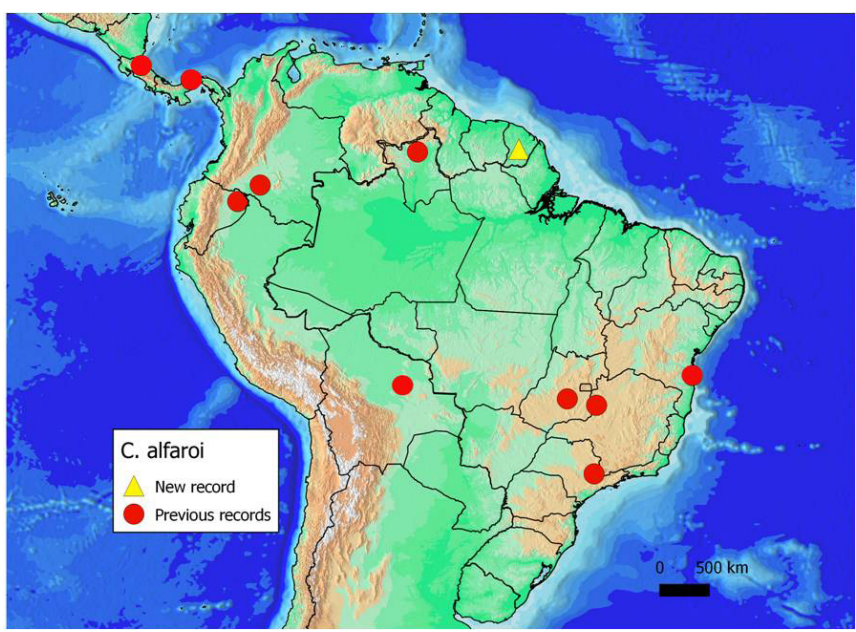

Fig 3. Distribution map of Centromyrmex alfaroi in the Neotropics based on literature records and the present study.

\section{Acknowledgements}

We thank to the Brazilian Council of Research and Scientific Development (CNPq) for supporter. WF (grant 130642/2016-9). RMF (grant 302462/2016-3).

\section{Reference}

Baccaro, F.B.; Feitosa, R.M.; Fernandez, F.; Fernandes, I.O.; Izzo, T.J.; Souza, J.P. de; Solar, R. (2015). Guia para os gêneros de formigas do Brasil. Manaus: Editora IMPA, 388 p.
Bestelmeyer, B.T.; Agosti, D.; Alonso, L.E.; Brandão, C.R.F; Brown, Jr W.L.; Delabie, J.H.C.; Silvestre, R. (2000). Field techniques for the study of ground-dwelling ants: an overview, description, and evaluation. In: Agosti, D.D.; Majer, J.D.; Alonso, L.E.; Schultz, T.R. (Eds.), Ants: Standard Methods for Measuring and Monitoring Biodiversity (pp.222-144). Washington: Smithsonian Institution Press.

Bolton, B. \& Fisher B.L. (2008). Afrotropical ants of the ponerine genera Centromyrmex Mayr, Promyopias Santschi gen. rev. and Feroponera gen. n., with a revised key to genera of African Ponerinae (Hymenoptera: Formicidae). Zootaxa, 1929: 1-37.

Dejean, A. \& Fénéron, R. (1999). Predatory behavior in the ponerinae ant, Centromyrmex bequaerti: a case of termitolesty. Behavioural Processes, 7: 125-133.

Delabie, J.H.C. (1995). Inquilinismo simultâneo de duas espécies de Centromyrmex (Hym., Formicidae, Ponerinae) em cupinzeiros de Syntermes sp. (Isoptera, Termitidae, Nasutermitinae). Revista Brasileira de Entomologia, 39: 605-609.

Dodds, K.J., Allison, J.D., Miller, D.R., Hanavan, R.P., Sweeney, J. (2015), Considering species richness and rarity when selecting optimal survey traps: comparisons of semiochemical baited flight intercept traps for Cerambycidae in eastern North America. Agricultural Forest Entomology, 17: 36-47. doi: 10.1111/ afe. 12078

Feitosa, R.M.; Silva, R.R.; Aguiar, A.P. (2016). Diurnal flight periodicity of a Neotropical ant assemblage (Hymenoptera, Formicidae) in the Atlantic Forest. Revista Brasileira de Entomologia, 60: 241-247. doi: 10.1016/j.rbe.2016.05.006

Kempf, W.W. (1967). A synopsis of the Neotropical ants of the genus Centromyrmex Mayr (Hymenoptera: Formicidae). Studia Entomologica, 9: 401-410.

Matthews, R.W. \& Matthews, J.R. (1971). The Malaise trap: its utility and potential for sampling insect populations. Michigan Entomologist, 4: 117-122.

McCravy, K.W.; Geroff, R.K; Gibbs, J. (2017). Malaise Trap Sampling Efficiency for Bees (Hymenoptera: Apoidea) in a Restored Tallgrass Prairie. Florida Entomologist, 99: 321323. doi: $10.1653 / 024.099 .0230$

Schmidt, C.A. \& Shattuck, S.O. (2014). The higher classification of the ant subfamily Ponerinae (Hymenoptera: Formicidae), with a review of ponerine ecology and behavior. Zootaxa, 3817: 1-242. doi: 10.11646/zootaxa.3817.1.1.

\section{Author contributions}

WF, RMF- Identified specimens, wrote the manuscript.

WF - compiled the data and prepared the distribution map. 